\title{
Studi Komparatif Mengenai Mindset antara Pria/Wanita yang Terikat Pernikahan dan Pria/Wanita yang Bercerai di Kota Bandung
}

\author{
Maria Carmelita Patricia Thomas, Cindy Maria \\ Universitas Kristen Maranatha \\ Corresponding E-mail: cindy.maria@psy.maranatha.edu
}

\begin{abstract}
This research was conducted to determine the differences about mindset between married man/woman and divorced man/woman in Bandung. Respondents in this study are man/woman who are married to only one person and man/woman who are divorced and have not remarried and are domiciled in Bandung. The sample in this study amounted to 100 people, 50 people who were married and 50 people who were divorced. The sampling technique used was snow ball sampling. Measurements were conducted with Mindset in Relationship measuring instrument which consists of 27 items. This measuring instrument has a validity range of 0,380,73 and reliability of 0,91. This study used the independent $t$-test technique to see the differences between mindset of married man/woman and divorced man/woman in Bandung. The results showed that there was a difference in the mindset between married man/woman and divorced man/woman in Bandung. The conclusion of this research is that married man/woman in Bandung have mindset that tends to be more growth, while divorced man/woman in Bandung have a more fixed mindset.
\end{abstract}

Keywords: growth mindset, fixed mindset, mindset in relationship, marriage, divorce

\begin{abstract}
Abstrak
Penelitian ini bertujuan untuk mengetahui perbedaan mindset antara pria/wanita yang terikat pernikahan dan pria/wanita yang bercerai di Kota Bandung. Responden pada penelitian ini merupakan pria/wanita yang terikat pernikahan hanya dengan satu orang, serta pria/wanita yang bercerai dan belum menikah lagi, berdomisili di Kota Bandung. Sampel dalam penelitian ini berjumlah 100 orang, 50 orang yang terikat pernikahan dan 50 orang yang bercerai. Teknik pengambilan sampel yang digunakan adalah snowball sampling. Pengukuran dilakukan dengan alat ukur Mindset in Relationship yang terdiri dari 27 aitem. Alat ukur ini memiliki validitas dengan rentang $0,38-0,73$ dan reliabilitas sebesar 0,91 . Penelitian ini menggunakan teknik uji independent $t$ test untuk melihat perbedaan mindset pada pria/wanita yang terikat pernikahan dan pria/wanita yang bercerai di Kota Bandung. Hasil penelitian menunjukkan adanya perbedaan mindset antara pria/wanita yang terikat pernikahan dan pria/wanita yang bercerai di Kota Bandung. Simpulan dari penelitian ini adalah pria/wanita yang terikat pernikahan di Kota Bandung memiliki mindset yang cenderung lebih growth, sementara pria/wanita yang bercerai di Kota Bandung memiliki mindset yang cenderung lebih fixed.
\end{abstract}

Kata Kunci: growth mindset; fixed mindset; mindset dalam relasi; pernikahan; perceraian 


\section{Pendahuluan}

Pernikahan adalah komitmen emosional dan hukum dari dua orang untuk membagi kedekatan emosional dan fisik, berbagi bermacam tugas dan sumber-sumber ekonomi (Olson \& deFrain, 2006). Pernikahan menyediakan keintiman, komitmen, persahabatan, cinta dan kasih sayang, pemenuhan seksual, pertemanan, dan kesempatan untuk pengembangan emosional seperti sumber baru bagi identitas dan harga diri (Gardiner \& Myres, dalam Papalia, Olds \& Feldman, 2004). Menikah merupakan hal yang lazim bagi masyarakat Indonesia. Dalam pernikahan, pria/wanita umumnya menginginkan kebahagiaan dan keharmonisan dalam berumah tangga, tujuan utama dalam menikah adalah mempunyai keluarga yang langgeng sampai ajal menjemput dan mempunyai partner dalam mengarungi kehidupan (Kholisotin, 2015). Sebagaimana yang dituliskan dalam Quran Surat (QN) Ar-Rum ayat 21 "Dan di antara tanda-tanda kekuasaan-Nya ialah Dia menciptakan untukmu isteriisteri dari jenismu sendiri, supaya kamu cenderung dan merasa tenteram kepadanya, dan dijadikanNya diantaramu rasa kasih dan saying (mawaddah warahmah). Sesungguhnya pada yang demikian itu benar-benar terdapat tanda-tanda bagi kaum yang berfikir", yang berarti bahwa dari pasangan suami istri itu akan tercipta ketenteraman diantara keduanya (Prihantoro, 2020). Mawaddah warahmah merupakan anugerah Allah yang diberikan kepada manusia, ketika manusia melakukan pernikahan (Wibisana, 2016).

Merujuk pada Q.S ar-Rum [30]: 21, manusia secara umum baik laki-laki maupun perempuan mendambakan pasangannya masing-masing agar memperoleh ketentraman (sakinah), dengan pondasi rasa dan sikap cinta (mawaddah) juga kasih (rahmah) dalam hidupnya. Tujuan tentram tersebut erat kaitannya dengan hal-hal yang bersifat biologis, ekonomi, sosial, keluarga (nasab), maupun moral-spiritual (din). Dalam ayat ini, Allah menetapkan ketentuan-ketentuan hidup suami istri untuk mencapai kebahagiaan hidup, ketenteraman jiwa, dan kerukunan hidup berumah tangga. Apabila hal itu belum tercapai, mereka semestinya mengadakan introspeksi terhadap diri mereka sendiri, meneliti apa yang belum dapat mereka lakukan serta kesalahan-kesalahan yang telah mereka perbuat. Kemudian mereka menetapkan cara yang paling baik untuk berdamai dan memenuhi kekurangan tersebut sesuai dengan ketentuan-ketentuan Allah, sehingga tujuan perkawinan yang diharapkan itu tercapai, yaitu ketenangan, saling mencintai, dan kasih sayang (Hardianti, 2020). Setiap pernikahan, selain cinta juga diperlukan pengertian antar pria dan wanita yang mendalam, kesediaan untuk saling menerima pasangan masing-masing. Hal ini berarti mereka juga harus bersedia menerima dan memasuki lingkungan sosial budaya pasangannya, sehingga diperlukan keterbukaan dan toleransi yang sangat tinggi, serta saling penyesuaian diri yang harmonis. Orang menikah bukan hanya mempersatukan diri, tetapi mempersatukan seluruh keluarga besarnya (Anjani, 2006).

Menurut Chairy (2006) tujuan pasangan menikah adalah untuk membentuk keluarga yang bahagia. Banyak hal yang perlu dipersiapkan dalam menghadapi pernikahan. Ketika suami dan istri berikrar untuk menikah, berarti masing-masing 'mengikatkan diri' pada pasangan hidup dan kebebasan sebagai individu 'dikorbankan'. Pernikahan bukan sebuah titik akhir, tetapi sebuah perjalanan panjang untuk mencapai tujuan yang disepakati berdua. Tiap pasangan harus terus belajar mengenai kehidupan bersama. Tiap pasangan juga harus kian menyiapkan mental untuk menerima kelebihan sekaligus kekurangan pasangannya dengan kontrol diri yang baik (Anjani, 2006). Hal yang paling penting adalah persiapan mental dari calon pasangan. Persiapan mental dimulai dari hal yang paling sederhana, yaitu mengenal dan memahami pasangan. Ketika pasangan memasuki kehidupan pernikahan, tidak berarti proses mengenal dan memahami berhenti. Masa awal pernikahan merupakan masa penyesuaian. Sebelum menikah, mungkin pria/wanita tidak mengetahui bahwa pasangannya terbiasa tidur dengan lampu menyala, atau terbiasa bekerja sambil mendengarkan musik. Selain itu 
pasangan juga harus menyamakan prinsip satu sama lain, seperti siapa yang mencari nafkah, siapa yang mengurus rumah tangga, kapan waktu yang tepat untuk memiliki anak, rencana untuk memiliki berapa anak, dll. Hal-hal seperti itu bisa memancing keributan di awal pernikahan apabila tidak dikomunikasikan dengan baik (Chairy, 2006).

Pentingnya penyesuaian dan tanggung jawab sebagai suami atau istri dalam sebuah pernikahan akan berdampak pada keberhasilan hidup berumah tangga. Keberhasilan dalam hal ini mempunyai pengaruh yang kuat terhadap adanya kepuasan hidup pernikahan, mencegah kekecewaan dan perasaan-perasaan bingung, sehingga memudahkan seseorang untuk menyesuaikan diri dalam kedudukannya sebagai suami atau istri dan kehidupan lain di luar rumah tangga (Hurlock, 2002). Pada kenyataannya, seringkali dijumpai bagaimana impian dan harapan untuk mewujudkan sebuah pernikahan yang bahagia dan sejahtera itu tidak tercapai, bagaimana sebuah pernikahan mengalami kegagalan dalam mewujudkan impian dan harapan bersama, serta bagaimana suatu permasalahan dapat timbul dalam kehidupan pernikahan, dan pada gilirannya dapat menjadi benih yang dapat mengancam kehidupan pernikahan serta mengakibatkan keretakan atau perceraian (Anjani, 2006).

Berdasarkan survey yang dilakukan Tim Badan Pusat Statistik Jawa Barat, dikatakan bahwa faktor penyebab perceraian terbesar di Jawa Barat adalah faktor ekonomi yaitu sebesar 43\%, lalu diikuti dengan perselisihan dan pertengkaran yaitu sebesar 34\%, meninggalkan salah satu pihak sebesar $14 \%$, kekerasan dalam rumah tangga sebesar $2 \%$, mabuk sebesar $0,5 \%$, poligami sebesar $0,3 \%$, judi sebesar 0,2\%, dan lain lain sebesar 6\% (Badan Pusat Statistik Jawa Barat, 2019). Salah satu hal yang bisa disoroti dari faktor perceraian yang dapat ditanggulangi dari sudut pandang ilmu psikologi yaitu perselisihan dan pertengkaran. Menurut Gottman (1999) perceraian akan terwujud jika masingmasing selalu melakukan kritik yang intinya menyalahkan pasangan, penghinaan atau merendahkan, pembelaan diri, dan membangun tembok-tembok pembatas untuk tidak berhubungan lagi. Sandstrom (2011) menemukan bahwa walaupun faktor terbesar yang mempengaruhi perceraian dalam abad ke dua puluh ini adalah fakor sosial-ekonomi, namun perlu juga diteliti mengenai pola stabilitas dalam keluarga. Bagaimana proses dalam keluarga dapat mempengaruhi perceraian individu. Apakah ketidakcocokan antar pasangan merupakan salah satu faktor yang dapat menyebabkan perceraian (White, 1990). Pemikiran ketidakcocokan merupakan persepsi yang berasal dari belief seseorang. Berdasarkan belief terhadap keberhasilan hubungan, individu terbagi menjadi dua, yaitu destiny belief dan growth belief. Individu yang memiliki destiny belief melihat pasangan sebagai kompatibel atau tidak, sementara individu yang memiliki growth belief melihat tantangan dalam hubungan pasti dapat dilalui (Knee, Patrick, \& Lonsbary, 2003). Dalam ranah hubungan romantis, ditemukan bahwa beliefs berkaitan dengan motivasi, goals, dan atribusi dalam proses interpersonal, sehingga dapat memprediksi relationship outcomes seperti reaksi terhadap konflik dan kepuasan (Knee,1998). Khususnya individu yang memiliki kepercayaan kuat pada destiny theories lebih memungkinkan untuk menetapkan dating goals jangka pendek, sehingga ia kurang berusaha untuk mengembangkan hubungan lalu berujung pada perasaan kurang puas terhadap hubungannya dibandingkan individu yang memegang kepercayaan kuat pada growth theories (Franiuk, Cohen, \& Pomerants, 2002).

Dalam hal ini, mindset yang dimiliki pria/wanita mempengaruhi bagaimana ia memandang kehidupan pernikahannya. Dweck (2006) menyatakan bahwa mindset merupakan keyakinan (belief) mengenai dasar dari atribut individu, seperti intelegensi atau kepribadian. Dweck membagi mindset menjadi dua bentuk yang bersifat kontinum yaitu fixed mindset dan growth mindset. Pria atau wanita dengan fixed mindset percaya bahwa atribut manusia merupakan suatu hal yang cenderung menetap, sehingga ada batasan yang tidak dapat ditembus oleh latihan maupun upaya manusia. Sementara pria atau wanita dengan growth mindset percaya bahwa potensi sesungguhnya dari seorang individu 
merupakan suatu hal yang tidak diketahui batasnya, sehingga mereka percaya bahwa dengan semangat, kerja keras, dan latihan kemampuan manusia dapat terus meningkat (Dweck, 2012).

Dalam setting pernikahan, keyakinan tersebut bukan hanya berlaku terhadap kualitas dirinya sendiri tetapi juga berlaku terhadap kualitas pasangan, dan kualitas hubungan (Beres, 2016). Pria/wanita dengan fixed mindset percaya bahwa kualitas diri sendiri, kualitas pasangan, dan kualitas hubungan merupakan hal yang menetap dan tidak bisa berkembang walaupun dengan usaha dan kerja keras sekalipun. Sementara, pria/wanita dengan growth mindset percaya bahwa kualitas diri sendiri, kualitas pasangan, dan kualitas hubungan merupakan hal yang tidak ada batasnya dan bisa terus berkembang melalui usaha dan kerja keras (Dweck, 2006).

Berdasarkan Dweck (2006) pria/wanita dengan growth mindset ditunjukkan dengan sikap tidak mudah menyerah, melihat tantangan atau masalah sebagai kesempatan untuk lebih mengenal pasangannya, menganggap proses dan usaha lebih penting dibandingkan hasil akhir, serta memandang kritik dari orang lain sebagai masukan untuk mengembangkan dirinya. Pria/wanita dengan growth mindset akan memilih hubungan yang bisa menantang dirinya untuk berkembang. Pasangan ideal bagi pria/wanita dengan growth mindset adalah orang yang bisa melihat kekurangannya dan membantu untuk menanganinya, dan mendorongnya untuk belajar hal baru. Pria/wanita dengan growth mindset percaya bahwa hubungan yang baik dan awet muncul dari usaha dan kerja keras untuk memahami perbedaan satu sama lain (Brownstein, 2018). Pria/wanita dengan growth mindset juga percaya bahwa tidak ada hal yang instan. Semua hal memerlukan usaha dan kerja keras, termasuk juga dalam hal hubungan dengan pasangan. Pria/wanita dengan growth mindset percaya bahwa sama seperti tidak ada pencapaian tanpa rintangan, maka tidak ada hubungan yang baik tanpa konflik dan masalah di dalamnya (Beres, 2016). Saat dihadapkan dengan suatu masalah, pria/wanita dengan growth mindset akan memilih untuk mengomunikasikan dan menyelesaikan masalah tersebut dengan pasangannya. Pria/wanita dengan growth mindset akan berpikir mengenai apa yang salah, lalu mencari tahu apa yang harus dilakukan selanjutnya. Seperti yang dituliskan dalam Al-Quran bahwa sikap dan perilaku untuk selalu bermusyawarah atau merembuk dan saling tukar pendapat dalam memutuskan sesuatu dalam rumah tangga adalah hal yang sangat penting. Melibatkan, mengajak berbicara dan musyawarah merupakan salah satu bentuk pengakuan dan penghargaan terhadap harga diri dan kemampuan pasangan. Dengan perbedaan sudut pandang yang digunakan dalam melihat suatu masalah oleh pasangan akan menjadikan keputusan sangat matang dengan kesadaran penuh akan manfaat dan akibat yang ditimbulkan dari keputusan tersebut (Hardianti, 2020).

Pria/wanita dengan growth mindset percaya bahwa komunikasi adalah kunci penting dari suatu hubungan. Ia tidak bisa mengetahui secara persis apa yang dipikirkan, dirasakan, atau dibutuhkan oleh pasangannya, oleh karena itu pria/wanita dengan growth mindset akan berusaha bertanya atau mengungkapkan pandangannya. Walaupun dihadapkan dengan kesulitan ekonomi, perbedaan pendapat dengan mertua, pertengkaran dengan pasangannya, pria/wanita dengan growth mindset tidak mudah menyerah dan bahkan memandang hal tersebut sebagai kesempatan untuk mengembangkan diri dan hubungannya. Dibandingkan menyalahkan pasangannya, pria/wanita dengan growth mindset akan berusaha memahami permasalahan yang terjadi dan mencoba untuk menanganinya bersama (Brownstein, 2018). Tidak ada yang menang atau kalah dalam hubungan mereka, hal yang terpenting adalah kedua belah pihak sama-sama dapat berkembang ke arah yang lebih baik. Dalam Al-Quran dituliskan "hunna libāsun lakum wa antum libāsun lahunna" (Q.S alBaqarah [2]: 187) yang berarti suami adalah pakaian untuk istri dan istri adalah pakaian untuk suami. Gambaran tersebut mengingatkan bahwa suami dan istri sebagai pasangan di antaranya harus saling 
menghangatkan, memelihara, menghiasi, menutupi, menyempurnakan juga memuliakan satu sama lain (Hardianti, 2020).

Di sisi lain, berdasarkan Dweck (2006) pria/wanita dengan fixed mindset ditunjukkan dengan sikap mudah menyerah, menghindari tantangan, menganggap hasil akhir lebih penting dibandingkan proses dan usaha yang dilakukan, dan memandang kritik dari pasangannya sebagai bentuk hinaan terhadap kesalahan atau kekurangan yang ia miliki. Pria/wanita dengan fixed mindset percaya bahwa dirinya terlahir dengan kemampuan, karakter, dan intelegensi yang terbatas, sehingga ia akan cenderung ingin menunjukkan bahwa kemampuan, karakter, dan intelegensi yang ia miliki memiliki kualitas yang bagus. Ia tidak ingin dipandang "bodoh" atau "gagal" oleh orang lain karena dengan menunjukkan kegagalannya berarti ia menunjukkan bahwa kemampuan, karakter, dan intelegensi dirinya yang terbatas itu memiliki kualitas yang buruk. Pria/wanita dengan fixed mindset tidak percaya bahwa usaha dan kerja keras dapat membuat seseorang menembus batas dirinya. Oleh karena itu pria/wanita dengan fixed mindset akan memilih hubungan yang dapat mendukung egonya. Pasangan ideal bagi pria/wanita dengan fixed mindset adalah orang yang bisa menjadi tumpuan, orang yang bisa membuat mereka merasa sempurna, dan memuja mereka. Dalam Al-Quran tertulis "tarädhin min humä" yaitu kerelaan dan penerimaan dari dua belah pihak. Kerelaan merupakan penerimaan paling puncak dan menimbulkan kenyamanan yang paripurna. Pasangan suami istri harus menjadikan pilar ini penyangga segala aspek baik itu perilaku, ucapan, sikap dan tindakan sehingga rumah tangga tidak hanya kokoh namun memberikan kebahagiaan dan rasa cinta kasih (Hardianti, 2020). Dalam hal ini pasangan yang memiliki kerelaan dan penerimaan terhadap pasangannya akan mendapatkan kebahagiaan dan rasa cinta kasih, dimana pria/wanita dengan fixed mindset dibandingkan menerima pasangannya justru menilai hubungan sebagai suatu hal yang good or bad atau meant-to-be or notmeant-to-be.

Pria/wanita dengan fixed mindset mengharapkan semua hal menyenangkan terjadi secara otomatis. Dalam suatu hubungan, pria/wanita dengan fixed mindset tidak memiliki pandangan bahwa pasangan bekerja membantu satu sama lain untuk menangani masalah. Pria/wanita dengan fixed mindset menganggap bahwa hubungan yang baik adalah hubungan dimana pasangan mampu memahami dan saling memenuhi kebutuhan satu sama lain tanpa usaha yang besar. Pria/wanita dengan fixed mindset percaya apabila pasangan kompatibel, maka semua hal yang baik akan datang secara alami. Oleh karena itu, saat dihadapkan dengan masalah, dibandingkan membahas dan menyelesaikan masalah tersebut dengan pasangannya, ia akan menganggap bahwa hubungan mereka tidak akan berhasil. Pria/wanita dengan fixed mindset percaya bahwa pasangan seharusnya bisa membaca pikiran satu sama lain. Pasangan seharusnya mengetahui apa yang saya pikirkan, rasakan, dan butuhkan, begitu juga sebaliknya. Oleh karena itu, pasangan tidak membutuhkan banyak komunikasi karena pasangan bisa melihat segala sesuatu sama seperti yang dirinya lihat. Saat terjadi masalah dalam hubungan pernikahan, akan lebih mudah untuk menyalahkan pasangan (Beres, 2016). Ia akan berusaha menghindari kesalahannya karena tidak ingin dipandang "gagal". Pria/wanita dengan fixed mindset akan berusaha untuk membuktikan kompetensi yang dimilikinya, maka dari itu Pria/wanita dengan fixed mindset akan cenderung berkompetisi dengan pasangannya. Siapa yang lebih pintar, lebih berbakat, dan lebih disukai. Ia ingin berada pada posisi yang setara atau melebihi pasangannya (Dweck, 2006). Dalam Al-Quran tertulis “mu'asyarah bil ma'ruf' atau sikap kesalingan, yaitu sikap saling memperlakukan satu sama lain secara baik. Perilaku berkompetisi dalam rumah tangga tidak mencerminkan adanya sikap saling memperlakukan satu sama lain dengan baik. Menumbuhkan prinsip kesalingan dalam rumah tangga akan membantu menjaga dan menghidupkan segala kebaikan yang menjadi tujuan bersama (Hardianti, 2020). 
Berdasarkan hasil wawancara yang dilakukan peneliti terhadap dua pria dan wanita yang menikah serta dua pria dan wanita yang bercerai, didapatkan bahwa kedua karakteristik pria/wanita dengan growth mindset dan fixed mindset ditemukan dalam pasangan yang menikah maupun yang bercerai. Pria/wanita yang memiliki growth mindset menganggap masalah dalam perkawinannya akan dapat diselesaikan, pasangannya dapat berubah. Selain itu, peneliti juga menemukan bahwa karakteristik fixed mindset pada individu dapat membuat dirinya memutuskan untuk tidak bercerai. Salah satu karakteristik pria/wanita dengan fixed mindset adalah tidak ingin dianggap "gagal" oleh orang lain. Berdasarkan hasil wawancara, karakteristik tersebut membuat pria/wanita mengurungkan niatnya untuk bercerai karena ia tidak ingin dipandang bahwa ia gagal dalam membina rumah tangga oleh orang-orang disekitarnya. Karakteristik fixed mindset juga bisa membuat pria/wanita tidak berekspektasi lebih pada pasangannya, sehingga membuat pria/wanita tidak menuntut lebih pada pasangan. Karakteristik pria/wanita dengan fixed mindset adalah percaya bahwa kemampuan, karakter, dan intelegensi yang dimiliki pasangannya merupakan hal yang menetap. Karakteristik tersebut membuat pria/wanita mengetahui batas kemampuan pasangannya dan tidak berekspektasi lebih terhadap pasangannya. Namun berdasarkan Dweck (2006) pria/wanita dengan growth mindset dan pria/wanita dengan fixed mindset akan memiliki perbedaan perilaku yang jelas, dalam hal ini khususnya perilaku dalam berelasi dengan pasangan.

Berdasarkan fenomena mindset yang dilihat pada pria/wanita yang menikah dan bercerai, maka penelitian ini bertujuan untuk melihat apakah terdapat perbedaan mindset antara pria/wanita yang terikat pernikahan dan pria/wanita yang bercerai di Kota Bandung. Hipotesis dalam penelitian ini adalah terdapat perbedaan mindset antara pria/wanita yang terikat pernikahan dan pria/wanita yang bercerai di Kota Bandung.

\section{Metode}

Penelitian ini merupakan penelitian kuantitatif dengan desain komparatif (Creswell, 2012) yang dilakukan secara cross sectional (Kumar, 2011). Karakteristik responden untuk pria/wanita yang terikat pernikahan pada penelitian ini adalah individu yang menjalani pernikahan pertama, hanya menikah dengan satu orang, dan berdomisili di Kota bandung, sementara karakteristik responden untuk pria/wanita yang bercerai pada penelitian ini adalah individu yang cerai hidup (bukan bercerai karena pasangannya meninggal), belum menikah lagi, dan berdomisili di Kota Bandung. Responden dijaring menggunakan Teknik snow ball sampling, yaitu proses pemilihan suatu sampel menggunakan jaringan/network (Sugiyono, 2018). Peneliti menyebarkan kuesioner kepada 30 orang dengan karakteristik yang sudah ditentukan sebelumnya, lalu 30 orang tersebut diminta untuk ikut menyebarkan kuesioner kepada kenalan yang memiliki karakteristik responden yang sesuai. Pengambilan data dilakukan selama kurang lebih 3 minggu dan didapatkan responden sebanyak 102 orang. Dari 102 data yang didapatkan, 2 data tidak dapat digunakan sehingga diperoleh sebanyak 100 data yang dapat diolah.

Lisa Friedenberg (1995), mengkategorikan koefisien validitas sebagai $\leq 0.30$ aitem ditolak yang berarti tidak dapat dipakai dan $>0.30$ aitem diterima yang berarti dapat dipakai. Berdasarkan uji validitas yang telah dilakukan dengan construct validity menggunakan uji Pearson yang dilakukan dengan bantuan program SPSS versi 22, dari total 30 aitem didapatkan 3 aitem yang memiliki koefisien korelasi $\leq 0.30$, sehingga aitem tersebut tidak digunakan. Oleh karena itu, dari 27 aitem yang digunakan didapatkan koefisien korelasi dengan rentang $0.38-0.73$, yang menyatakan bahwa aitemaitem pada alat ukur ini valid. Nilai reliabilitas Cronbach Alpha dari alat ukur yang digunakan pada penelitian ini adalah 0.91 yang menyatakan bahwa alat ukur ini memiliki nilai reliabilitas yang sangat tinggi. 
Pengumpulan data dilakukan menggunakan teknik survey berupa kuesioner dalam bentuk google form. Alat ukur yang digunakan dalam penelitian ini adalah alat ukur mindset in relationship yang disusun oleh peneliti berdasarkan teori mindset dari Dweck (2006). Peneliti menyusun alat ukur baru dikarenakan alat ukur mindset yang disusun oleh Dweck hanya mengukur mindset secara umum yaitu keyakinan mengenai intelegensi, bakat, dan sifat, keyakinan akan tantangan, kesulitan, dan kegagalan, keyakinan mengenai usaha dan kerja keras, serta keyakinan terhadap kritik dan masukan dari orang lain, sedangkan dalam penelitian ini selain keyakinan terhadap kualitas diri dibutuhkan juga data mengenai keyakinan terhadap kualitas pasangan dan keyakinan terhadap kualitas hubungan, sehingga peneliti menyusun alat ukur baru yang dapat mengukur ketiga aspek tersebut. Kuesioner ini disusun untuk mengukur mindset dalam pernikahan, sehingga aitem-aitem yang digunakan memiliki topik seputar pasangan dan kehidupan pernikahan. Teknik analisis data yang digunakan dalam penelitian ini adalah uji independent t-test. Uji Independent t-test digunakan untuk mengetahui apakah terdapat perbedaan rata-rata antara dua kelompok independen/bebas (Damayanti, 2019).

\section{Hasil Penelitian}

Tabel 1. Gambaran Sampel Penelitian

\begin{tabular}{|c|c|c|}
\hline Karakteristik & Jumlah & Persentase $(\%)$ \\
\hline \multicolumn{3}{|l|}{ Jenis kelamin } \\
\hline Perempuan & 82 & $82 \%$ \\
\hline Laki-laki & 18 & $18 \%$ \\
\hline \multicolumn{3}{|l|}{ Usia } \\
\hline 18-39 tahun (early adulthood) & 31 & $31 \%$ \\
\hline 40-60 tahun (middle adulthood) & 68 & $68 \%$ \\
\hline$>60$ tahun (late adulthood) & 1 & $1 \%$ \\
\hline \multicolumn{3}{|c|}{ Usia pernikahan (Pria/wanita yang menikah) } \\
\hline $1-3$ tahun & 5 & $10 \%$ \\
\hline 4-6 tahun & 3 & $6 \%$ \\
\hline 7-9 tahun & 2 & $4 \%$ \\
\hline 10-12 tahun & 3 & $6 \%$ \\
\hline 13-15 tahun & 2 & $4 \%$ \\
\hline 16-18 tahun & 7 & $14 \%$ \\
\hline 19-21 tahun & 10 & $20 \%$ \\
\hline 22-24 tahun & 7 & $14 \%$ \\
\hline 25-27 tahun & 7 & $14 \%$ \\
\hline 28-30 tahun & 3 & $6 \%$ \\
\hline 31-33 tahun & 1 & $2 \%$ \\
\hline \multicolumn{3}{|c|}{ Usia pernikahan (Pria/wanita yang bercerai) } \\
\hline $1-3$ tahun & 15 & $30 \%$ \\
\hline 4-6 tahun & 7 & $14 \%$ \\
\hline 7-9 tahun & 5 & $10 \%$ \\
\hline 10-12 tahun & 8 & $16 \%$ \\
\hline 13-15 tahun & 5 & $10 \%$ \\
\hline 16-18 tahun & 5 & $10 \%$ \\
\hline 19-21 tahun & 2 & $4 \%$ \\
\hline 22-24 tahun & 1 & $2 \%$ \\
\hline
\end{tabular}


25-27 tahun

28-30 tahun

\section{1}

1

$2 \%$

$2 \%$

\section{Penyebab Perceraian}

\section{KDRT}

Perselingkuhan

Ketidakcocokan

Perbedaan agama

Mencuri aset keluarga

Masalah pekerjaan

Ekonomi

Masalah keluarga pasangan

Ditinggal pasangan (tanpa kabar)

$\begin{array}{ll}1 & 2 \% \\ 1 & 2 \% \\ 7 & \\ 15 & 14 \% \\ 17 & 30 \% \\ 2 & 34 \% \\ 1 & 4 \% \\ 1 & 2 \% \\ 1 & 2 \% \\ 3 & 2 \% \\ 3 & 6 \% \\ & 6 \%\end{array}$

Pada tabel 1 terdapat data demografis bahwa sebanyak $82 \%$ responden berjenis kelamin perempuan dan sebanyak $18 \%$ responden berjenis kelamin laki-laki. Sebagian besar responden memiliki rentang usia 40-60 tahun (middle adulthood), dengan rata-rata usia 44 tahun. Sebagian besar pria/wanita yang menikah memiliki usia pernikahan 19-21 tahun, sementara sebagian besar pria/wanita yang bercerai memiliki usia pernikahan 1-3 tahun sebelum bercerai. Penyebab perceraian terbesar adalah ketidakcocokan yaitu sebesar $34 \%$.

Tabel 2. Hasil Komparasi Penelitian

\begin{tabular}{cccccccc}
\hline & Sig. & Kelompok & N & $\boldsymbol{M}$ & M1 & M2 & M3 \\
\hline \multirow{2}{*}{ Mindset } & 0.000 & Menikah & 50 & 4.6676 & 4.80 & 4.40 & 4.65 \\
\cline { 3 - 7 } & & Bercerai & 50 & 4.0056 & 4.38 & 3.47 & 3.74
\end{tabular}

Catatan: M1=Kualitas Diri, M2=Kualitas Pasangan, M3= Kualitas Hubungan

Pada tabel 2, disajikan matriks komparasi antara mindset pria/wanita yang terikat pernikahan dan pria/wanita yang bercerai di Kota Bandung diperoleh sig. (2-tailed) $=0,000$ dengan probabilitas $=$ $0,00<0,05$. Hal ini menunjukkan bahwa $\mathrm{H}_{0}$ dalam penelitian ini ditolak, dengan kata lain terdapat perbedaan yang signifikan antara mindset pria/wanita yang terikat pernikahan dan pria/wanita yang bercerai di Kota Bandung. Secara komparatif pria/wanita yang terikat pernikahan di Kota Bandung menunjukkan rata-rata mindset yang lebih tinggi dibandingkan pria/wanita yang bercerai di Kota Bandung. Hal itu menunjukkan bahwa pria/wanita yang terikat pernikahan di Kota Bandung memiliki mindset yang cenderung lebih growth dibandingkan pria/wanita yang bercerai di Kota Bandung.

\section{Diskusi}

Pada tabel 2 dapat dilihat bahwa pria/wanita yang terikat pernikahan di Kota Bandung memiliki rata-rata skor kepercayaan terhadap kualitas diri, rata-rata skor kepercayaan terhadap kualitas pasangan, dan rata-rata skor kepercayaan terhadap kualitas hubungan yang dikategorikan sebagai growth mindset. Hal ini menunjukkan bahwa pria/wanita yang terikat pernikahan di Kota Bandung percaya bahwa kualitas diri, kualitas pasangan, dan kualitas hubungan pernikahan yang ia miliki merupakan hal yang dapat dikembangkan dengan usaha dan kerja keras. Pria/wanita yang terikat pernikahan di Kota Bandung percaya bahwa kemampuan, karakter, potensi, dan intelegensi yang ia dan pasangannya miliki bukan merupakan hal yang menetap dan dapat berkembang dengan usaha dan kerja keras. Ia memandang konflik bukan hanya sebagai tantangan untuk mengembangkan 
dirinya, tetapi juga sebagai alat untuk mengembangkan karakter pasangannya serta sarana untuk mempererat hubungan pernikahannya (Dweck, 2006).

Pada tabel 2 dapat dilihat bahwa berdasarkan rata-rata skor keseluruhan, pria/wanita yang bercerai di Kota Bandung dikategorikan ke dalam growth mindset. Namun jika dilihat rata-rata skor per-aspek, maka didapatkan bahwa rata-rata skor kepercayaan terhadap kualitas pasangan dan rata-rata skor kepercayaan terhadap kualitas hubungan pada pria/wanita yang bercerai di Kota Bandung dikategorikan sebagai fixed mindset, sementara rata-rata skor kepercayaan terhadap kualitas diri dikategorikan sebagai growth mindset. Hal ini sejalan dengan yang diungkapkan Dweck (2006) bahwa setiap individu bisa memiliki mindset yang berbeda terhadap aspek yang berbeda-beda dalam kehidupannya, mereka bisa memiliki fixed mindset terhadap aspek tertentu dan growth mindset terhadap aspek yang lainnya. Pria/wanita yang bercerai di Kota Bandung memiliki growth mindset terhadap kualitas dirinya. Hal ini menunjukkan bahwa pria/wanita yang bercerai di Kota Bandung percaya bahwa kemampuan, karakter, potensi, dan intelegensi yang dimilikinya bukan merupakan hal yang menetap dan dapat berkembang dengan usaha dan kerja keras. Ketika pria/wanita yang bercerai di Kota Bandung dihadapkan dengan situasi konflik atau pertengkaran, ia akan menganggap hal tersebut sebagai tantangan untuk mengembangkan dirinya menjadi lebih baik, namun ia tidak menganggap hal yang serupa terjadi pada pasangannya.

Di sisi lain, pria/wanita yang bercerai di Kota Bandung menganggap bahwa usaha dan kerja keras tidak dapat mengubah sikap ataupun kebiasaan buruk yang dimiliki pasangannya. Mereka percaya bahwa pasangannya terlahir dengan karakter yang menetap, selain itu mereka juga percaya bahwa kualitas hubungannya merupakan hal tidak bisa diubah, sehingga saat dihadapkan dengan konflik atau pertengkaran, pria/wanita yang bercerai di Kota Bandung akan menganggap masalah ini sebagai tantangan untuk mengembangkan dirinya menjadi lebih baik namun tidak untuk pasangannya. Ia percaya bahwa karakter yang dimiliki pasangannya tidak bisa berubah walaupun dengan usaha dan kerja keras sekalipun, sehingga setiap kali dihadapkan dengan konflik pria/wanita yang bercerai di Kota Bandung akan menganggap bahwa hanya dirinya yang berusaha keras untuk berubah, namun pasangannya tidak bisa mengubah kebiasaan buruknya.

Hal tersebut cenderung membuat pria/wanita yang bercerai di Kota Bandung percaya bahwa ia dan pasangannya tidak ditakdirkan untuk bersama dan mereka menganggap bahwa pertengkaran tersebut membuat hubungan pernikahan mereka menjadi buruk. Pria/wanita yang bercerai di Kota Bandung percaya bahwa usaha dan kerja keras tidak dapat mengubah kondisi hubungan mereka, sehingga mereka cenderung memutuskan untuk bercerai. Hal ini juga terlihat dari data pada tabel 1 bahwa sebanyak 34\% (17 orang), mengatakan bahwa alasan perceraian mereka adalah karena ketidakcocokan antara dirinya dan pasangan.

Hal ini sejalan dengan teori mindset in relationship yang diungkapkan Dweck (2006) bahwa pria/wanita dengan fixed mindset akan cenderung menilai hubungan mereka sebagai cocok-tidakcocok atau meant-to-be or not-meant-to-be. Tidak semua pasangan terlahir cocok sejak awal, Gottman (1999) mengatakan bahwa dalam setiap pernikahan terdapat tekanan yang dapat memisahkan pasangan dan menyatukan pasangan, sehingga hal yang terpenting dalam sebuah hubungan adalah usaha dan kerja keras untuk memahami satu sama lain agar hubungan pernikahan tetap berada di jalur yang tepat.

Berdasarkan tabel 1 dapat dilihat bahwa sebagian besar pria/wanita yang bercerai di Kota Bandung memiliki usia pernikahan 1-3 tahun sebelum akhirnya memutuskan untuk bercerai. Pasangan suamiistri yang baru menikah perlu beradaptasi dengan kebiasaan pasangan serta kebiasaan keluarga pasangannya. Ekspektasi dan norma baru dari keluarga pasangannya bisa saja menjadi tekanan bagi 
pria/wanita yang baru menikah (Adrian, 2019). Ia juga perlu menyesuaikan diri dengan peran barunya sebagai suami/istri. Ada banyak hal baru yang harus dihadapi bersama, seperti berbagi tugas rumah tangga, mengelola keuangan, urusan dengan mertua, menyempatkan waktu untuk berhubungan seksual, hingga mendiskusikan tujuan-tujuan hidup bersama (Adrian, 2019).

Menurut Chairy (2006) masa awal pernikahan adalah masa penyesuaian diri yang menyulitkan bagi pria/wanita yang baru menikah karena seringkali banyak terjadi hal yang tidak pernah dibayangkan sebelumnya. Banyak kebiasaan-kebiasaan yang baru diketahui setelah pria/wanita menikah. Banyak istri atau suami yang mengeluh bahwa sifat dan sikap pasangannya berubah setelah menikah, tidak seperti saat pacaran (Herman, dalam Agustia 2010). Oleh karena itu, masa awal pernikahan merupakan masa rentan terjadinya konflik dalam kehidupan pernikahan. Apabila tidak diikuti dengan growth mindset dalam menghadapi konflik tersebut, maka perceraian menjadi rentan terjadi.

Beres (2016) mengatakan bahwa mindset yang dimiliki pria atau wanita dapat mempengaruhi bagaimana mereka menjalani hubungan berpasangan. Penting untuk memiliki growth mindset terhadap kualitas pasangan dan kualitas hubungan. Pria/wanita dengan growth mindset akan memandang pasangan dan kondisi hubungan sebagai sesuatu yang bisa berubah dengan usaha dan kerja keras, sehingga ia tidak akan mudah menyerah dan akan berusaha keras untuk mengembangkan dirinya, diri pasangannya, dan kondisi hubungan pernikahannya. Brownstein (2018) mengatakan bahwa dibandingkan terus menerus menuntut pasangan untuk memenuhi ekspektasi, pria/wanita dengan growth mindset akan berusaha untuk meningkatkan kapasitas untuk mengasihi pasangannya. Growth mindset juga bisa membuat hubungan pernikahan menjadi lebih harmonis, pasangan bisa lebih menghormati dan menghargai satu sama lain (Dweck, 2006). Hal ini menunjukkan pentingnya growth mindset dalam kehidupan pernikahan.

\section{Kesimpulan}

Berdasarkan hasil penelitian komparatif mengenai mindset yang dilakukan kepada pria/wanita yang terikat pernikahan dan pria/wanita yang bercerai di Kota Bandung, dapat disimpulkan bahwa terdapat perbedaan mindset pada pria/wanita yang terikat pernikahan dan pria/wanita yang bercerai di Kota Bandung. Pria/wanita yang terikat pernikahan di Kota Bandung memiliki mindset yang termasuk dalam kategori growth, dengan tiga aspek di dalamnya (kualitas diri, kualitas pasangan, dan kualitas hubungannya) yang termasuk dalam kategori growth mindset juga. Artinya pria/wanita yang terikat pernikahan di Kota Bandung percaya bahwa kualitas diri, kualitas pasangan, dan kualitas hubungan bukan suatu hal yang menetap melainkan dapat berubah dan berkembang dengan usaha dan kerja keras. Sementara pria/wanita yang bercerai di Kota Bandung memiliki mindset yang termasuk dalam kategori growth, dengan growth mindset terhadap kualitas diri dan fixed mindset terhadap kualitas pasangan dan kualitas hubungannya. Artinya pria/wanita yang bercerai di Kota Bandung percaya bahwa kualitas diri merupakan suatu hal yang dapat berkembang dengan usaha dan kerja keras, namun kualitas pasangan dan kualitas hubungan merupakan suatu hal yang menetap dan tidak dapat diubah walaupun dengan usaha dan kerja keras sekalipun.

Dari hasil penelitian yang sudah dilakukan, maka peneliti menyarankan hal-hal sebagai berikut: 1) Penelitian selanjutnya disarankan untuk melihat seberapa besar pengaruh mindset terhadap perceraian dengan melakukan analisis regresi; 2) Dalam proses penelitian ini ditemukan juga beberapa kekurangan yakni keterbatasan responden yang disebabkan oleh adanya kondisi pandemi global, sehingga disarankan untuk penelitian selanjutnya, jumlah responden dapat diperbanyak agar hasil penelitian lebih representatif dan semakin bisa digeneralisasikan pada kriteria responden yang serupa; 3) Penerapan praktis yang dapat dilakukan berdasarkan hasil penelitian ini adalah bagi pasangan 
suami istri, diharapkan dapat lebih menghargai usaha dan kerja keras pasangan, mau mendengarkan, mengakui kesalahan, dan tidak menyalahkan pasangan. Percaya bahwa setiap permasalahan yang dihadapi ada jalan keluarnya dan dapat diatasi.

\section{Daftar Pustaka}

Adrian, Kevin. (2019). Alasan 2 Tahun Pertama Pernikahan Sangat Penting untuk Masa Depan. https://www.alodokter.com/alasan-2-tahun-pertama-pernikahan-sangat-penting-untuk-masadepan.

Agustia, Emy. (2010). Usia-usia Pernikahan Rentan Masalah. https://ifestyle.kompas.com/read/2010/01/23/09432140/usia_usia.pernikahan.rentan.masalah.

Anjani, Cinde \& Suryanto. (2006). Pola Penyesuaian Perkawinan pada Periode Awal. Universitas Airlangga: Fakultas Psikologi.

Badan Pusat Statistik Jawa Barat. (2019). Provinsi Jawa Barat Dalam Angka. Badan Pusat Statistik Jawa Barat.

Beres, Derek. (2016). Why Mindset is Critical in Successful Relationship. https://bigthink.com/21stcentury-spirituality/why-mindset-is-critical-in-successful-relationships.

Brownstein, Barry. (2018). Love Only Last with a Growth Mindset. https://fee.org/articles/love-onlylasts-with-a-growth-mindset/.

Chairy, Liche Seniati. (2006). Psikologi Perkawinan. Fakultas Psikologi Universitas Indonesia.

Creswell, J. W. (2012). Educational Research: Planning, Conducting, and Evaluating Quantitative and Qualitative Research ( $4^{\text {th }} \mathrm{ed}$ ). Boston: Pearson.

Damayanti, Elfana, dkk. (2019). Makalah Statistika Induktif: Uji Paired Sample T-Test, Uji Independent Sample T-Test, dan Uji Wilcoxon. Departemen Ekonomika dan Bisnis, Universitas Gajah Mada.

Dweck, Carol S. (2006). Mindset: The New Psychology of Success. New York: Random House.

Dweck, Carol S. (2012). Mindsets and Human Nature: Promoting Change in the Middle East, the Schoolyard, the Racial Divide, and Willpower. Standord University.

Franiuk, R., Cohen, D., \& Pomerantz, E. M. (2002). Implicit theories of relationships: Implications for relationship satisfaction and longevity. Personal Relationships, 9, 345-367.

Friedenberg, Lisa, 1995. Psychological Testing: Design, Analysis and Use. Boston: Allyn \& Bacon.

Gottman, J. M. \& Silver, N. (1999). The Seven Principles for Making Marriage Work. New York: Three Rivers Press.

Hardianti, Mida. (2020). Lima Pilar Kehidupan Rumah Tangga dalam Al-Quran Menurut Faqihuddin Abdul Kodir. https://tafsiralquran.id/lima-pilar-kehidupan-rumah-tangga-dalamal-quran/.

Hurlock, E.B. (2002). Psikologi Perkembangan 5th edition. Erlangga: Jakarta.

Kholisotin, Umi. (2015). Pernikahan Dini di Dusun Palu Desa Karang Pinang Kecamatan Kembang Kabupaten Bojonegoro: Tinjauan Dramaturgi. Undergraduate thesis: UIN Sunan Ampel Surabaya.

Knee, C. R., Patrick, H., \& Lonsbary, C. (2003). Implicit theories of relationships: Orientations toward evaluation and cultivation. Personality and Social Psychology Review, 7, 
$41-55$.

Knee, R. (1998). Implicit theories of relationships: Assessment and prediction of romantic relationship initiation and longevity. Journal of Personality and Social Psychology, 74, $360-370$.

Kumar, R. (2011). Research Methodology: A Step-By-Step Guide for Beginners. SAGE.

MO, L. (2016). A Review of The Determinants of Divorce: A Cross-National Perspective. International Journal of Sociology of the Family, 42(1/2), 29-47.

Olson, D.H. \& DeFrain, J. (2006). Marriages \& Families. Boston: McGrawHill.

Papalia, D.E, Olds, S.W., \& Feldman, R.D. (2004). Human Development $\left(9^{\text {th }} e d\right)$. New York: McGraw Hil.

Prihantoro, Anom. (2020). Psikolog: Lima Pilar Pernikahan dalam Islam. https://www.antaranews.com/berita/1472367/psikolog-lima-pilar-pernikahan-dalamislam\#mobile-nav.

Sandstrom, Glenn. (2011). Socio-economic Determinants of Divorce in Early Twentieth-Century Sweden. Centre for Population Studies and Centre for Gender Studies, Umeå University.

Santrock, John W. (2011). Life-Span Development (13 ${ }^{\text {th }}$ ed). New York: McGraw-Hill.

Sugiyono. (2018). Metode Penelitian Kuantitatif. Bandung: Alfabeta.

White, Lynn K. (1990). Determinants of Divorce: A Review of Research in the Eighties. University of Nebraska-Lincoln.

Wibisana, Wahyu. (2016). Pernikahan dalam Islam. Universitas Pendidikan Indonesia: Departemen Pendidikan Umum FPIPS. 